\title{
(10СD) $\begin{aligned} & \text { ДОСЛІДЖЕННЯ } \\ & \text { МОЛОДИХ НАУКОВЦІВ }\end{aligned}$
}

UDC 331.5

\author{
A.V. SEMYKINA \\ Post-graduate student, \\ Kyiv National Economic University Named \\ after Vadym Hetman - self-governing (autonomous) research university \\ 03680, 54/1 Prospect Peremogy, 03680, Kyiv, Ukraine \\ E-mail: a.semikina@gmail.com
}

\section{HUMAN CAPITAL COMPETITIVENESS AND METHODS OF ITS ESTIMATION}

On the basis of the theoretical analysis of scientific thoughts the essence of the human capital competitiveness is revealed. The existing scientific approaches to a competitiveness assessment in the labor sphere are systematized. The necessity of an assessment support and regulation of the available human capital competitiveness in Ukraine according to the western requirements against the background of prospects of European integration of Ukraine is proved. Scientific and methodical approaches to the human capital competitiveness assessment at the medium economic level are suggested and approved. The list of human capital competitiveness components and indicators is proposed. The matrix of the human capital competitiveness is calculated using the statistics of Ukrainian regions.

Key words: human capital, competitiveness, sphere of work, competitive advantages, assessment, region, matrix of competitiveness of the human capital.

\author{
А.В. Семикіна \\ аспірант, ДВНЗ «Київський національний економічний \\ університет імені Вадима Гетьмана» \\ E-mail: a.semikina@gmail.com
}

\section{КОНКУРЕНТОСПРОМОЖНІСТЬ ЛЮДСЬКОГО КАПІТАЛУ ТА МЕТОДИ ІІЇ ОЦІНЮВАННЯ}

На основі теоретичного аналізу наукової думки розкрито сутність конкурентоспроможності людського капіталу. Систематизовано існуючі підходи до оцінки конкурентоспроможності у сфері праці. Запропоновано та апробовано науково-методичний підхід до оцінки конкурентоспроможності людського капіталу на мезоекономічному рівні. Розраховано матрицю конкурентоспроможності людського капіталу на прикладі регіонів України.

Ключові слова: людський капітал, конкурентоспроможність, сфера праці, конкурентні переваги, оцінювання, регіон, матриия конкурентоспроможності людського капіталу. 


\author{
А.В. Семикина \\ аспирант, ГВУЗ «Киевский национальний \\ экономический университет имени Вадима Гетьмана» \\ E-mail: a.semikina@gmail.com

\section{КОНКУРЕНТОСПОСОБНОСТЬ ЧЕЛОВЕЧЕСКОГО КАПИТАЛА И МЕТОДЫ ЕЁ ОЦЕНИВАНИЯ}

На основе теоретического анализа научной мысли раскрыта сущность конкурентоспособности человеческого капитала. Систематизированы существующие подходы к оценке конкурентоспособности в сфере труда. Предложен и апробирован научно-методический подходк оценке конкурентоспособности человеческого капитала на мезоэкономическом уровне. Рассчитана матрица конкурентоспособности человеческого капитала на примере регионов Украины.

Ключевые слова: человеческий капитал, конкурентоспособность, сфера труда, конкурентные преимущества, оценка, регион, матрица конкурентоспособности человеческого капитала.

Introduction. In the modern globalized world competitiveness of the states, regions, organizations or companies is defined not so much by the advantages in the volumes of material or financial resources, but much more by the human capital, in particular by its intellectual development, ability to quickly to acquire and produce new knowledge, to develop and introduce more and more innovations, offer new production, goods, services which are increasingly in demand on the market. The strengthening of international competition causes the constant necessity to support and increase the human capital competitiveness in every possible way that, in turn, demands an adequate methodology of its assessment at various economic levels. For Ukraine these questions have special relevance taking into account the strategic tasks of the entry to the European Union, however their solutions are broken by a lack of methods of the human capital competitiveness assessment.

Problem definition. The purpose of the article is to justify the essence of the human capital competitiveness, and to systematize and improve the scientific and methodical approaches to its assessment.

Results of research. Prospects of entry of Ukraine to the European Union bear not only obvious benefits, but also certain risks of competitiveness decline as for the domestic producers, their production, services, so for the human capital. The danger of transformation of Ukraine into the supplier of cheap (though educated) labor for further work in Europe doesn't suit Ukrainians. At the same time an overwhelming part of the Ukrainian employees risk experiencing a loss of competitiveness in the conditions of the honest competition in European integration, because they all work at the enterprises which significantly lag behind western ones concerning the conditions of technical and technological development, are characterized by the low level of intellectualization of workplaces, don't provide acquisition of high qualification of the personnel. So, threats of noncompetitiveness grow both for such enterprises, which are major in Ukraine, and for the workers employed by them. Loss of workplaces, income, social security can turn out to be a consequence of noncompetitiveness of the human capital for its many bearers.

Against the background of prospects of European integration of Ukraine the requirement of an assessment and support, regulation of the available human capital competitiveness in Ukraine according to the western requirements concerning knowledge, practical skills, competences, mobility, adaptability of workers to the new production technologies and etc. objectively increases. 
The analysis of researches and publications on labor economy shows that the human capital was differently investigated both by the foreign (T. Shults, G. Becker, J. Kendrick, F. Makhlup, R. Kapelyushnikov, Yu. Korchagin), and by domestic scientists (O. Grishnova, V. Antonyuk, E. Libanova, T. Zayats, A. Kolot, L. Mikhaylova, O. Zakharova, I. Lapshina, etc.). At the same time, despite considerable theoretical practices in this direction, it should be noted that aspects of the human capital competitiveness still belong to the least studied questions. The designated perspective still remains the less-studied direction of the scientific researches not only for the domestic, but also for foreign scientists. The analysis of publications shows that the question of the human capital competitiveness is generally studied in Ukraine and less in Russia, Belarus, Moldova.

The greatest surge of scientific activity in the direction of studying of essence of competitiveness in the labor sphere was observed in Ukraine in the late nineties of the XX c. and at the beginning of the 2000s that was explained by searching for ways of formation and regulation of the competitive environment and labor market. However, the approaches to understanding and assessment of competitiveness in the labor sphere still cause brisk discussions because in domestic and foreign literature studying of the competitiveness phenomena on the example of production, goods, enterprises, countries is still much more widespread.

The systematization of scientific approaches to understanding of the competitiveness in labor sphere carried out by us showed that the interpretation of the term «competitiveness» in the labor sphere is still not unambiguous. It is possible to be convinced of this, analyzing the approaches to understanding of competitiveness in the labor sphere, which are provided in Table 1. Authors variously explain the essence of competitiveness, covering the publications on the subjects of the labor force analysis, personnel, labor potential, and only recently - human capital $[2 ; 3 ; 5 ; 6 ; 9 ; 12 ; 13 ; 15 ; 16]$.

Developing scientific thoughts stated in publications $[1 ; 2 ; 3-7 ; 9 ; 12]$, we suggest understanding the human capital competitiveness as existence of competitive advantages among the quantitative and qualitative characteristics, which are formed and saved up by training, education, health improvement of certain employees, groups of employees, employed population of the region, country in general, and their realization promotes obtaining bigger income, accumulation of the specified advantages, improvement of competitive positions of certain economic subjects and country in general.

However, nowadays it is possible to claim surely that it is time to enrich the idea of determination of competitiveness in the labor sphere with approaches based on the positions of the human capital theory. It is advisable in the conditions of formation of the global competitive environment, to prompt innovative processes in the world when human capital competitiveness became a key factor of preservation (or loss) of country's competitive positions in the world (as, by the way, of the economic subjects at markets).

Developing known approaches of the scientists investigating a perspective of the human capital (works written by O. Grishnova, V. Antonyuk, L. Mikhaylova, etc.), we consider that the assessment of its competitiveness can occur at the different levels of the economic analysis, concerning both the general (complex) assessment of competitiveness, and a comparative assessment of competitive advantages of separate qualitative characteristics of the human capital health, educational and professional development, labor motivation, ability to innovations, mobility, labor activity, etc.). 
Table 1. Scientific thoughts concerning competitiveness in labor sphere

\begin{tabular}{|c|c|c|}
\hline Concept & & Authors, essence of approach \\
\hline \multirow{11}{*}{ 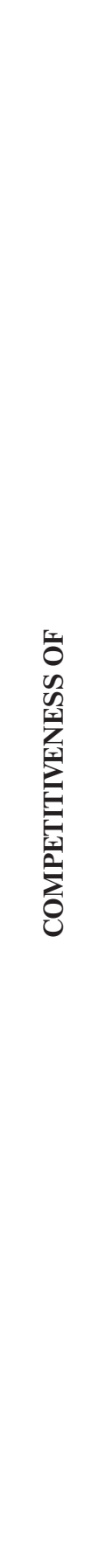 } & \multirow{5}{*}{ 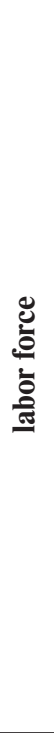 } & $\begin{array}{l}\text { O. Grishnova: «Compliance of labor force's quality to the market requirements, } \\
\text { opportunity to win the competition at labor market, means to meet the require- } \\
\text { ments of employers concerning level of knowledge, abilities, skills and personal } \\
\text { qualities, better than other candidates» [3, page 117]. }\end{array}$ \\
\hline & & $\begin{array}{l}\text { D. Bogynya: «Set of qualitative and cost characteristics of specific good «labor } \\
\text { force», which provides the satisfaction of specific needs of employers for workers } \\
\text { of a certain qualification (profession)» }[2, \text { page } 4]\end{array}$ \\
\hline & & $\begin{array}{l}\text { M. Semykina: «Set of natural, educational and professional, business and moral } \\
\text { qualities of workers which are the most greatly demanded on a certain market seg- } \\
\text { ment during a certain period of market conditions, allowing to perform labor tasks } \\
\text { qualitatively and in the conditions of competition to reach the best realization of } \\
\text { employer's interests and personnel's requirements...» [12, page 23] }\end{array}$ \\
\hline & & $\begin{array}{l}\text { L. Lisogor: «...Organic unity of quantitative and qualitative characteristics of labor } \\
\text { force which are characterized by a market demand» }[5 \text {, page } 34] \text {. }\end{array}$ \\
\hline & & $\begin{array}{l}\text { O. Tsymbal: «...Ability of people through a competitive type of work to provide } \\
\text { themselves with conditions for realization of personal economic and social intere- } \\
\text { sts» }[17 \text {, page } 220] \text {. }\end{array}$ \\
\hline & \multirow{2}{*}{ 总 } & $\begin{array}{l}\text { O. Slavgorodska: «Ability to realize the available competitive advantages to promo- } \\
\text { te the advance of the enterprise at the best competitive position in comparison with } \\
\text { other subjects of the competition at this market» [13]. }\end{array}$ \\
\hline & & $\begin{array}{l}\text { I. Tsvetkova: «Set of personal and professional characteristics of the personnel } \\
\text { which reflect and characterize the joint actions of all personnel, its ability to provi- } \\
\text { de competitiveness of the enterprise» [16, page 73] }\end{array}$ \\
\hline & 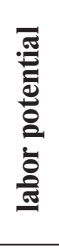 & $\begin{array}{l}\text { D. Ratnikov: «Achievement of advantages in quantitative and qualitative charac- } \\
\text { teristics of formation, use and development of labor potential (health, education, } \\
\text { professional competence, labor and innovative activity, motivation to effective } \\
\text { work and educational, professional development, etc.) who allow the enterprise } \\
\text { and its personnel to receive economic, social and moral benefits in the conditions } \\
\text { of the competitive environment» [9, page 95] }\end{array}$ \\
\hline & \multirow{3}{*}{ 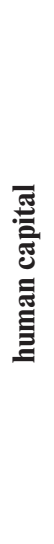 } & $\begin{array}{l}\text { M. Nikolaychuk: «Existence of assets at the disposal of the subject of competitive } \\
\text { relations which are created on the basis of suitable for application during the com- } \\
\text { petition of the elements and characteristics of human potential capable to provide } \\
\text { the achievement of favorable conditions, receiving resources, achievement and } \\
\text { keeping of market, social or economic positions, material and non-material effects } \\
\text { and the benefits, goals of activity» [6, page 212] }\end{array}$ \\
\hline & & $\begin{array}{l}\text { I. Kurevina «Set of quantitative and qualitative characteristics of employees which } \\
\text { meet the requirements of economic subjects and satisfy their needs for a certain } \\
\text { qualification level of hired personnel» }[4, \text { page } 7]]\end{array}$ \\
\hline & & $\begin{array}{l}\text { G. Hafizova: «It is characterized by a set of qualitative parameters }- \text { level of know- } \\
\text { ledge, abilities, skills, personal characteristics..., thinking creativity, innovative and } \\
\text { informational activity, that allows to use the firm's personnel better..» }[15 \text {, } \\
\text { page 73]. }\end{array}$ \\
\hline
\end{tabular}

Note: this is systematized by author using the data of $[2-6,9,12,13,15,16]$. 
The analysis of scientific thoughts allows concluding that techniques of the human capital competitiveness assessment can differ depending on the purposes of analysis and aspects which are taken into account. It is confirmed convincingly by the systematization of the existing approaches to the competitiveness assessment (of personnel, labor, labor potential) which we show in the Table $2[1 ; 7 ; 10 ; 12 ; 14]$.

Without reducing ponderability of scientific achievements, in particular, in Table 2, we focus attention at the expediency of development of competitiveness assessment methods from positions of the human capital theory, pressing problems of regulation of human capital quality in the conditions of strengthening of competitive character of labor relations at the different economic levels.

In the course of the theoretical analysis to broaden the sphere of scientific search on the basis of interdisciplinary approaches and to address the general scientific achievements in different areas of economic science concerning competitiveness assessment questions, it was recognized expedient to be guided by M. Porter's ideas about the competition and statements of the human capital theory revealed by G. Becker and T. Schultz and developed by their followers, in particular in Ukraine. We consider expedient to apply to the analysis of the human capital competitiveness using the analog of Porter five forces analysis of the competition [8].

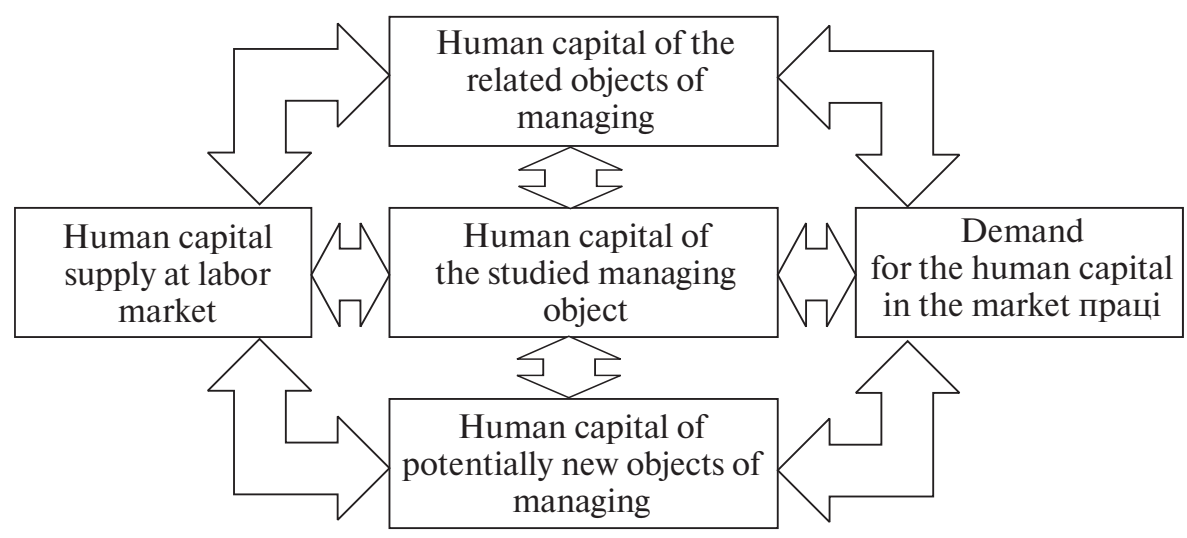

Fig. 1. The scheme of the Porter five forces of the competition model on the example of human capital (developed by the author on the basis of development of M. Porter's ideas [8])

Considering the provided scheme it is possible to conclude that the various aspects of the human capital competitiveness assessment obtain value: on the example of various objects of managing; at different economic levels; from positions of demand assessment, labor market requirements and compliance to these requirements.

The improvement of methods, ways, technologies, methodologies, in general, which concerned an assessment of the human capital competitiveness, are used, in our opinion, to help managers to define to what degree and through which components, parameters, characteristics of human capital quality they lag from other competing subjects of labor, what does lead to the losses of possible benefits from use of the human capital, in particular, decline of labor productivity, income, social, economic and innovative effects of labor. 
Table 2. Methodical approaches to competitiveness assessment in labor sphere

\begin{tabular}{|c|c|}
\hline $\begin{array}{c}\text { Auth- } \\
\text { ors }\end{array}$ & Essence of methodical approaches \\
\hline 1 & 2 \\
\hline 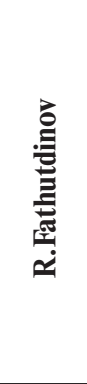 & $\begin{array}{l}\text { The assessment of competitiveness of concrete personnel category is carried out proceeding } \\
\text { from its competitive advantages which can be external and internal concerning personnel. } \\
\qquad \mathrm{K}_{\mathrm{n}}=\sum_{\mathrm{i}=1}^{\mathrm{n}} \sum_{\mathrm{j}=1}^{7} \frac{\left(\alpha_{\mathrm{i}} \cdot \beta_{\mathrm{ij}}\right)}{5 \cdot \mathrm{n}} \\
\text { where } \mathrm{K}_{\mathrm{n}}-\text { competitiveness of a particular category of staff, } \mathrm{n} \text { - number of experts, } 7-\mathrm{qu}- \\
\text { antity and quality of personnel to be considered, } \alpha_{\mathrm{i}}-\text { importance of quality, } \beta_{\mathrm{ij}}-\text { Expert } \\
\text { assessment of quality personnel in the five-point system: } 1-\text { no quality } 2-\text { appears rarely, } \\
3-\text { appears not much and not weakly } 4 \text { - appears often, } 5 \text { - appears systematically [14, } \\
\text { p. 259-260]. }\end{array}$ \\
\hline 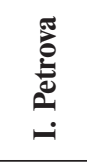 & $\begin{array}{l}\text { Comprehensive competitiveness assessment is carried out using the point } \alpha_{\mathrm{ij}} \text { and significance } \\
\beta_{\mathrm{ij}} \text { criteria used to it [7,p.155]: } \\
\qquad \mathrm{K}_{\mathrm{i}}=\sum \alpha_{\mathrm{ii}} \times \beta\end{array}$ \\
\hline 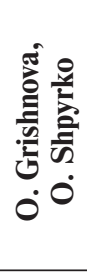 & $\begin{array}{l}\text { The starting position is considered that personnel competitiveness is a function from its qu- } \\
\text { ality and price of use therefore employee's competitiveness is offered to be defined as a ratio } \\
\text { of a quantitative assessment of quality to the price [1, page } 8] \text {, thus the technique provides } \\
\text { application of a point method of assessment and use of weighting coefficients to determine } \\
\text { the ponderability of separate competitiveness indicators [1,p. 8]: } \\
\text { Competitiveness = Quantitative assessment of quality/Price } \\
\qquad \mathrm{w}_{\mathrm{i}}=\mathrm{r}_{\mathrm{i}} / \sum \mathrm{r}_{\mathrm{i}}\end{array}$ \\
\hline 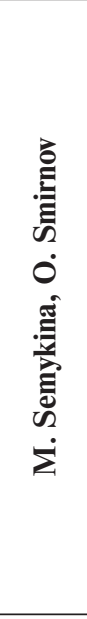 & $\begin{array}{l}\text { Knowledge and practical skills are identified with integrated characteristics of supply and } \\
\text { demand for the services concerning labor, a set of parameters } \mathrm{p} 1, \mathrm{p} 2, \ldots, \mathrm{p} \text {, each of which } \\
\text { has the scale of measurement so that for each employee there is possible a clarification of size } \\
\text { of the supply of his services at labor market }\left(\mathrm{p}_{11}, \mathrm{p}_{21}, \ldots, \mathrm{p}_{\mathrm{N} 1}\right) \text { and demand for them }\left(\mathrm{p}_{12}, \mathrm{p}_{22} \text {, }\right. \\
\left.\ldots, \mathrm{p}_{\mathrm{N} 2}\right) \text {. } \\
\text { The coefficient of employee competitiveness is calculated using separately taken parameter pi } \\
{[12, \mathrm{p} .126-129] \text { : }} \\
\qquad k_{i}=\left|p_{i}{ }^{1}-p_{i}{ }^{2}\right| / \max p_{i} \text {, } \\
\text { and indicator of employee competitiveness }(\mathrm{K}) \text { in general: } \\
\qquad K=\left(\alpha_{1} * k_{1}+\alpha_{2} * k_{2}+. .+\alpha_{N} * k_{N}\right) /\left(\alpha_{1}+\alpha_{2}+. .+\alpha_{N}\right) \\
\text { where } \alpha_{1}, \alpha_{2}, \ldots, \alpha_{\mathrm{N}}-\text { coefficients, which assess the significance of employee competitive- } \\
\text { ness for a particular individual parameter } \mathrm{p}_{\mathrm{i}} \text {. }\end{array}$ \\
\hline 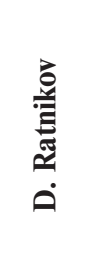 & $\begin{array}{l}\text { Competitiveness of labor }(\mathrm{K}) \text { is defined as a product of labor quality coefficient (K1) by labor } \\
\text { (of a certain level of quality at labor market) need coefficient (K2) [10, p. 8]: } \\
\qquad \mathrm{K}=\mathrm{K}_{1} \cdot \mathrm{K}_{2}, \\
\mathrm{~K} 1=\Pi / \mathrm{B}, \quad \mathrm{K}_{2}=\mathrm{P} / \mathrm{Y} \\
\text { where } \Pi \text { - professional standard of labor, B - expenses on labor training, } \\
\mathrm{P} \text { - need of labor market for labor of a certain quality, } \\
\mathrm{Y} \text { - number of professionally trained labor. }\end{array}$ \\
\hline
\end{tabular}

Note: this is systematized by author using the data of $[1,7,10,12,14]$. 
Developing the existing approaches to competitiveness assessment and considering possibility of their adaptation to the human capital competitiveness assessment on the basis of separation of a subset of analyzed objects together with the characteristics of their competitive factors, we suggest the vision of methodical bases of the human capital competitiveness assessment. Our scientific and methodical approach to an assessment of the human capital competitiveness provides accounting for such components:

$n$ - object of analysis ( $\mathrm{n}=1 . . \mathrm{N}, \mathrm{N}-$ total number of objects of analysis). It is worth noting that depending on consideration level certain employees or groups of employees of various departments of enterprise, or labor staff of various enterprises, or the employed population act as an object of the analysis;

$k_{n i}$ - value of competitive factor $i$ (i=1..I; the total number of competing factors) of object of analysis $n$ (as competitive factors on macro-, medium level «demographic development», «development of labor market», «material welfare», «accommodation conditions», «education level», «condition of health care», at a microlevel - health, capacity for work, educational level, qualification, competence, mobility, experience, labor productivity, income, labor and innovative activity, etc.);

$p_{n m i}$ - indicator of competitiveness of an object of analysis $n$ in comparison with object of the analysis $m$ by a competitive factor $i$.

Among indicators of competitiveness, theoretically possible for calculation, we suggest to use comparison of relative type - with advantage on particle from division:

$p_{n m i}=k_{n i}-k_{m i}$,

- if pnmi $p_{n m i}>1(=1,<1)$, than an object of analysis $n$ by competitive factor $i$ more (equal, less) competitive, than an object $m$.

Matrix of the human capital competitiveness is formed by the set of objects of analysis $n=1 . . \mathrm{N}$ for each of the competitive factors $i=1$..I:

$$
\left[\begin{array}{cccc}
\mathrm{p}_{11 \mathrm{i}} & \mathrm{p}_{12 \mathrm{i}} & \ldots & \mathrm{p}_{1 \mathrm{Ni}} \\
\mathrm{p}_{21 \mathrm{i}} & \mathrm{p}_{22 \mathrm{i}} & \ldots & \mathrm{p}_{2 \mathrm{Ni}} \\
\ldots & \ldots & \ldots & \ldots \\
\mathrm{p}_{\mathrm{N} 1 \mathrm{i}} & \mathrm{p}_{\mathrm{N} 2 \mathrm{i}} & \ldots & \mathrm{p}_{\mathrm{NNi}}
\end{array}\right]
$$

The analysis of a whole set of such matrixes at the set of $i=1 . . I$ reveals almost all the variations of competitiveness indexes for each separate competitive factor in comparison of each object of analysis $n$ with other $m_{l}, m_{2}$, detecting:

- more competitive objects of analysis $\left(p_{n m l i}>p_{n m 2 i}\right)$,

- equally competitive objects of analysis $\left(p_{n m l i}=p_{n m z i}\right)$,

- less competitive objects of analysis $\left(p_{n m l i}<p_{n m 2 i}\right)$, and, in particular,

- the most competitive: $p_{n m i}=\max \left\{p_{n m i} ; \forall m=1 . . N\right\}$ and

- the least competitive: $p_{n m i}=\min \left\{p_{n m i} ; \forall m=1 . . N\right\}$.

In general, taking into consideration inequivalent competitive factors meaning their «influence» $\omega_{\mathrm{i}}$, which can be done using the expert method, it is possible to define the «generalized» index of the human capital competitiveness:

$$
P n m=\sqrt[I]{\prod_{i=1}^{I} \varpi_{i} \cdot p_{n m i}}, \quad \forall n, m=1 . . N .
$$


Table 3. Matrix of the human capital competitiveness generalized indicators by regions of Ukraine

\begin{tabular}{|c|c|c|c|c|c|c|c|c|c|c|c|c|}
\hline Region & $\mathrm{N}$ & 1 & 2 & 3 & 4 & 5 & 6 & 7 & 8 & 9 & 10 & 11 \\
\hline Vinnytsia & 1 & 1,000 & 0,978 & 0,997 & 0,992 & 1,045 & 0,894 & 0,951 & 0,979 & 0,943 & 1,050 & 0,989 \\
\hline Volyn & 2 & 1,022 & 1,000 & 1,019 & 1,014 & 1,068 & 0,914 & 0,972 & 1,001 & 0,963 & 1,074 & 1,011 \\
\hline Dnipropetrovsk & 3 & 1,003 & 0,981 & 1,000 & 0,995 & 1,048 & 0,897 & 0,954 & 0,982 & 0,945 & 1,054 & 0,992 \\
\hline Donetsk & 4 & 1,008 & 0,986 & 1,005 & 1,000 & 1,053 & 0,901 & 0,958 & 0,986 & 0,950 & 1,058 & 0,997 \\
\hline Zhytomyr & 5 & 0,957 & 0,936 & 0,954 & 0,949 & 1,000 & 0,856 & 0,909 & 0,936 & 0,902 & 1,005 & 0,946 \\
\hline Transcarpathia & 6 & 1,118 & 1,094 & 1,115 & 1,110 & 1,169 & 1,000 & 1,063 & 1,095 & 1,054 & 1,175 & 1,106 \\
\hline Zaporizhia & 7 & 1,052 & 1,029 & 1,049 & 1,044 & 1,100 & 0,941 & 1,000 & 1,030 & 0,992 & 1,105 & 1,040 \\
\hline Ivano-Frankivsk & 8 & 1,022 & 0,999 & 1,018 & 1,014 & 1,068 & 0,914 & 0,971 & 1,000 & 0,963 & 1,073 & 1,010 \\
\hline Kiev & 9 & 1,061 & 1,038 & 1,058 & 1,053 & 1,109 & 0,949 & 1,008 & 1,038 & 1,000 & 1,114 & 1,049 \\
\hline Kirovohrad & 10 & 0,952 & 0,931 & 0,949 & 0,945 & 0,995 & 0,851 & 0,905 & 0,932 & 0,897 & 1,000 & 0,941 \\
\hline Lugansk & 11 & 1,011 & 0,989 & 1,008 & 1,004 & 1,057 & 0,904 & 0,961 & 0,990 & 0,953 & 1,062 & 1,000 \\
\hline Lviv & 12 & 1,096 & 1,072 & 1,093 & 1,088 & 1,146 & 0,980 & 1,042 & 1,073 & 1,033 & 1,151 & 1,084 \\
\hline Nicholas & 13 & 1,044 & 1,021 & 1,041 & 1,036 & 1,091 & 0,933 & 0,992 & 1,022 & 0,984 & 1,096 & 1,032 \\
\hline Odessa & 14 & 1,034 & 1,011 & 1,031 & 1,026 & 1,081 & 0,924 & 0,983 & 1,012 & 0,974 & 1,086 & 1,022 \\
\hline Poltava & 15 & 1,046 & 1,024 & 1,043 & 1,038 & 1,094 & 0,936 & 0,995 & 1,024 & 0,986 & 1,099 & 1,035 \\
\hline Rivne & 16 & 1,008 & 0,986 & 1,005 & 1,000 & 1,053 & 0,901 & 0,958 & 0,986 & 0,950 & 1,058 & 0,996 \\
\hline Sumy & 17 & 0,977 & 0,956 & 0,974 & 0,970 & 1,021 & 0,874 & 0,929 & 0,956 & 0,921 & 1,026 & 0,966 \\
\hline Ternopil & 18 & 1,010 & 0,988 & 1,007 & 1,003 & 1,056 & 0,904 & 0,960 & 0,989 & 0,952 & 1,061 & 0,999 \\
\hline Kharkiv & 19 & 1,138 & 1,114 & 1,135 & 1,130 & 1,190 & 1,018 & 1,082 & 1,114 & 1,073 & 1,196 & 1,126 \\
\hline Kherson & 20 & 0,966 & 0,945 & 0,963 & 0,959 & 1,010 & 0,864 & 0,919 & 0,946 & 0,911 & 1,015 & 0,956 \\
\hline Khmelnytsky & 21 & 1,003 & 0,981 & 1,000 & 0,995 & 1,048 & 0,897 & 0,953 & 0,982 & 0,945 & 1,054 & 0,992 \\
\hline Cherkasy & 22 & 1,018 & 0,996 & 1,015 & 1,010 & 1,064 & 0,910 & 0,968 & 0,997 & 0,960 & 1,069 & 1,007 \\
\hline Chernivtsi & 23 & 1,114 & 1,090 & 1,110 & 1,105 & 1,164 & 0,996 & 1,059 & 1,090 & 1,050 & 1,170 & 1,101 \\
\hline Chernihiv & 24 & 1,007 & 0,985 & 1,004 & 0,999 & 1,052 & 0,900 & 0,957 & 0,985 & 0,949 & 1,057 & 0,995 \\
\hline
\end{tabular}

Note: Calculated using the data from [11, p. 54]; calculations are carried out using formula (11) applied to the components of the regional human development «population reproduction», «social environment», «comfortable life», «prosperity», «decent work», «education». 


\begin{tabular}{|c|c|c|c|c|c|c|c|c|c|c|c|c|c|}
\hline 12 & 13 & 14 & 15 & 16 & 17 & 18 & 19 & 20 & 21 & 22 & 23 & 24 & $\begin{array}{l}\text { Competit- } \\
\text { iveness ra- } \\
\text { ting among } \\
\text { regions }\end{array}$ \\
\hline 0,912 & 0,958 & 0,967 & 0,956 & 0,992 & 1,024 & 0,990 & 0,879 & 1,035 & 0,997 & 0,982 & 0,898 & 0,993 & 20 \\
\hline 0,933 & 0,979 & 0,989 & 0,977 & 1,014 & 1,046 & 1,012 & 0,898 & 1,058 & 1,019 & 1,004 & 0,918 & 1,015 & 10 \\
\hline 0,915 & 0,961 & 0,970 & 0,959 & 0,996 & 1,027 & 0,993 & 0,881 & 1,038 & 1,000 & 0,985 & 0,901 & 0,996 & 18 \\
\hline 0,919 & 0,965 & 0,975 & 0,963 & 1,000 & 1,031 & 0,997 & 0,885 & 1,043 & 1,005 & 0,990 & 0,905 & 1,001 & 15 \\
\hline 0,873 & 0,917 & 0,925 & 0,914 & 0,949 & 0,979 & 0,947 & 0,840 & 0,990 & 0,954 & 0,940 & 0,859 & 0,950 & 23 \\
\hline 1,020 & 1,071 & 1,082 & 1,069 & 1,110 & 1,145 & 1,107 & 0,982 & 1,157 & 1,115 & 1,098 & 1,004 & 1,111 & 2 \\
\hline 0,960 & 1,008 & 1,018 & 1,005 & 1,044 & 1,077 & 1,041 & 0,924 & 1,088 & 1,049 & 1,033 & 0,945 & 1,045 & 6 \\
\hline 0,932 & 0,979 & 0,988 & 0,976 & 1,014 & 1,046 & 1,011 & 0,898 & 1,057 & 1,019 & 1,003 & 0,917 & 1,015 & 11 \\
\hline 0,968 & 1,016 & 1,026 & 1,014 & 1,053 & 1,086 & 1,050 & 0,932 & 1,098 & 1,058 & 1,042 & 0,953 & 1,054 & 5 \\
\hline 0,869 & 0,912 & 0,921 & 0,910 & 0,945 & 0,974 & 0,942 & 0,836 & 0,985 & 0,949 & 0,935 & 0,855 & 0,946 & 24 \\
\hline 0,923 & 0,969 & 0,978 & 0,966 & 1,004 & 1,035 & 1,001 & 0,888 & 1,046 & 1,008 & 0,993 & 0,908 & 1,005 & 13 \\
\hline 1,000 & 1,050 & 1,060 & 1,047 & 1,088 & 1,122 & 1,085 & 0,963 & 1,134 & 1,093 & 1,077 & 0,984 & 1,089 & 4 \\
\hline 0,952 & 1,000 & 1,010 & 0,997 & 1,036 & 1,068 & 1,033 & 0,917 & 1,080 & 1,041 & 1,025 & 0,937 & 1,037 & 8 \\
\hline 0,943 & 0,990 & 1,000 & 0,988 & 1,026 & 1,058 & 1,023 & 0,908 & 1,070 & 1,031 & 1,015 & 0,928 & 1,027 & 9 \\
\hline 0,955 & 1,003 & 1,012 & 1,000 & 1,039 & 1,071 & 1,036 & 0,919 & 1,083 & 1,043 & 1,028 & 0,940 & 1,040 & 7 \\
\hline 0,919 & 0,965 & 0,975 & 0,963 & 1,000 & 1,031 & 0,997 & 0,885 & 1,043 & 1,005 & 0,990 & 0,905 & 1,001 & 16 \\
\hline 0,891 & 0,936 & 0,945 & 0,934 & 0,970 & 1,000 & 0,967 & 0,858 & 1,011 & 0,974 & 0,960 & 0,877 & 0,971 & 21 \\
\hline 0,922 & 0,968 & 0,977 & 0,966 & 1,003 & 1,034 & 1,000 & 0,888 & 1,045 & 1,007 & 0,992 & 0,907 & 1,004 & 14 \\
\hline 1,038 & 1,091 & 1,101 & 1,088 & 1,130 & 1,165 & 1,127 & 1,000 & 1,178 & 1,135 & 1,118 & 1,022 & 1,131 & 1 \\
\hline 0,882 & 0,926 & 0,935 & 0,924 & 0,959 & 0,989 & 0,957 & 0,849 & 1,000 & 0,964 & 0,949 & 0,868 & 0,960 & 22 \\
\hline 0,915 & 0,961 & 0,970 & 0,959 & 0,995 & 1,027 & 0,993 & 0,881 & 1,038 & 1,000 & 0,985 & 0,901 & 0,996 & 19 \\
\hline 0,929 & 0,975 & 0,985 & 0,973 & 1,010 & 1,042 & 1,008 & 0,894 & 1,053 & 1,015 & 1,000 & 0,914 & 1,011 & 12 \\
\hline 1,016 & 1,067 & 1,077 & 1,064 & 1,105 & 1,140 & 1,102 & 0,978 & 1,152 & 1,110 & 1,094 & 1,000 & 1,106 & 3 \\
\hline 0,918 & 0,964 & 0,974 & 0,962 & 0,999 & 1,030 & 0,996 & 0,884 & 1,042 & 1,004 & 0,989 & 0,904 & 1,000 & 17 \\
\hline
\end{tabular}


The specified allows creating of the generalized competitiveness matrix for all possible couples of objects of analysis $n, m$ in a whole set of competitive factors $i=1$..I (and in case of need, its any subsets):

$$
\left[\begin{array}{cccc}
\mathrm{P}_{11} & \mathrm{P}_{12} & \ldots & \mathrm{P}_{1 \mathrm{~N}} \\
\mathrm{P}_{21} & \mathrm{P}_{22} & \ldots & \mathrm{P}_{2 \mathrm{~N}} \\
\ldots & \ldots & \ldots & \ldots \\
\mathrm{P}_{\mathrm{N} 1} & \mathrm{P}_{\mathrm{N} 2} & \ldots & \mathrm{P}_{\mathrm{NN}}
\end{array}\right]
$$

The outlined methodical approach to an assessment of the human capital competitiveness was approved at a medium economic level. The assessment of the human capital competitiveness at the regional level is formed by the generalized matrix of the human capital competitiveness of Ukrainian regions (assessment is made for 24 regions of Ukraine - except Kyiv, Sevastopol, AR Crimea, see Table 3). Calculation of the given matrix is based on application of the technique suggested above and statistics of regional human development for 2012 [11, page 54]. As competitive factors the indexes of «population reproduction», «social environment», «comfortable life», «welfare», «worthy work», «education» were chosen.

The generalized competitiveness indicator calculated by the formula (11) shows, how many times does the competitiveness of the object presented by a table line number is more or less than competitiveness of the object, comparable to it presented by number of a table column.

So, the human capital of Vinnytsia region (line number 1) estimated for all competitive factors used in the analysis makes 0,978 times from the human capital competitiveness of Volyn' region (column number 2). Being backward 19 regions from the 24 analyzed, this region holds the 20th place in a rating of the human capital competitiveness which is noted by the last column of Table 3.

Among the leaders for the generalized indicator of the human capital competitiveness we find the following:

- Kharkiv region (the I position in a competitiveness rating);

- Transcarpathian region (II rating position);

- Chernivtsi and Lviv regions. (III and IV ranking position, correspondingly).

Regions-outsiders by an indicator of human capital competitiveness are: Kirovograd, Zhitomir, Kiev, Sumy, Vinnytsia regions (correspondingly, rating positions 24, 23, 22, 21 , 20, see Table 3).

Concerning the analysis of separate objects and sets of competitive factors, the proposed way of the human capital competitiveness assessment allows revealing by comparisons more (less, equally) competitive groups for each of them, so for their set, promotes expansion of limits of the analysis to make a weighed administrative decisions concerning detecting the regulatory influence on the human capital quality.

In the same way it is obviously possible to carry out an assessment of the human capital competitiveness (of personnel) at the level of the enterprises, labor collectives, certain employees. Thus the competitive advantages are defined as within indicators of health, capacity for work, education, competence, mobility, labor productivity, income, etc., and in the form of the integrated indicator allowing to build more reasonable system of motivational management at the enterprises. 
Conclusions. Thus, prospects of entry of Ukraine into EU demand special attention of scientists to the problem of human capital competitiveness and improvement of its assessment methodology which has to become the basis of its quality increase according to today's requirements. The scientific and methodical approach to the assessment of the human capital competitiveness, worked out in the article at a regional economic level favors socially responsible choice of administrative decisions concerning development and use of the human capital, ensuring the regulation of its competitive qualities. Further scientific researches have to be connected with the development of the human capital competitiveness increase mechanism.

\section{LITERATURA}

1. Грішнова O.A. Конкурентоспроможність персоналу підприємства: критерії визначення та показники вимірювання / Грішнова О., Шпирко О. // Україна: аспекти праці. -2004. № 3. - С.3 -9 .

2. Богиня Д.П. Концептульні підходи до визначення конкурентоспроможності робочої сили на ринку праці / Д. Богиня // Україна: аспекти праці. - 1999. - № 6. - С. 3-8.

3. Грішнова О.А. Формування якості робочої сили та конкурентоспроможності працівника в процесі інвестування в людський капітал / О.А. Грішнова // Конкурентоспроможність у сфері праці : зб. наук. праць. - К.: Ін-т економіки НАН України, 2001. - С.117 - 126.

4. Куревіна I.О. Конкурентоспроможність людського капіталу України в умовах міжнародної трудової міграції : автореф. дис. канд. екон. наук: 08.00.02 / І.О. Куревіна; НАН України, Ін-т світ. економіки і міжнар. відносин. - К., 2008. - 20 с.

5. Лісогор Л.С. Конкурентність на ринку праці: механізми реалізації : монографія / Відпов. ред. Е.М. Лібанова. - К.: Ін-т демографії та соціальних досліджень НАНУ, 2005. - 168 с.

6. Ніколайчук М.В. Конкурентоспроможність людського капіталу в системі сучасних чинників розвитку економіки знань / М.В. Ніколайчук // Економічний аналіз : зб. наук. праць. ТНЕУ. Тернопіль : ВПЦ ТНЕУ, 2011. - Вип. 9. - Ч. 3. - С. 211-214.

7. Петрова I.Л. Сегментація ринку праці: теорія і практика регулювання. - К.: Ін-т економіки, управління та господарського права, 1997. - 298 с.

8. Портер М. Международная конкуренция. - М.: Международные отношения, 2001. - 211с.

9. Ратніков Д.Г. Конкурентоспроможність трудового потенціалу і перспективи економічного зростання / Д.Г. Ратніков // Резерви підвищення ефективності діяльності підприємств та організацій у XXI ст. : Тези доповідей учасників Всеукр. наук.-практ. конф. молодих вчених, аспірантів та студентів - Кіровоград: КНТУ, 2008. - С. 95-96.

10. Ратніков Д.Г. Методика оцінки рівня конкурентоспроможності робочої сили // Україна: аспекти праці. -2006. - № 1. - С. 8-12.

11. Регіональний людський розвиток. Статистичний бюлетень.- К.: Державна служба статистики, 2013.- $60 \mathrm{c}$.

12. Семикіна М.В. Конкурентоспроможність персоналу підприємства: теорія і практика регулювання [монографія] / М.В. Семикіна, О.О. Смірнов; За ред. Семикіної М.В. - Кіровоград: КОД, 2008. $-208 \mathrm{c}$.

13. Славгородська О.Ю., Щербак В.Г. Класифікація конкурентних переваг персоналу підприємства // Наукові праці ДонНТУ: Серія Економічна, 2005. - № 8. - С. 94-101.

14. Фатхутдинов Р.А. Конкурентоспособность организации в условиях кризиса: экономика, маркетинг, менеджмент. - М.: Маркетинг, 2002. - 892 с.

15. Хафизова Г.С. Развитие инновационности и конкурентоспособности человеческого капитала / Г.С. Хафизова // Креативная экономика. - 2012. - № 1 (61). - С. 72 -82. [Электронный ресурс]. - Режим доступа: http://www.creativeconomy.ru/articles/15311/

16. Цветкова И.И. Управление конкурентоспособностью персонала предприятия : Монография. - Симферополь: ДОЛЯ, 2007. - 240 с.

17. Цимбал О.I. До визначення категорії конкурентоспроможності стосовно робочої сили в умовах функціонування економіки перехідного типу. - К.: РВПС України, 1999. - Вип. 9. C. 216-227. 


\section{REFERENCES}

1. Grishnova, O.A. (2004). Konkurentospromozhnist' personalu pidpryyemstva: kryteriyi vyznachennya ta pokaznyky vymiryuvannya [Personnel competitiveness: criteria definition and measurements]. Ukrayina: aspekty pratsi - Ukraine: labor aspects, 3, 3-9 [in Ukrainian]

2. Bohynya, D.P. (1999). Kontseptul'ni pidkhody do vyznachennya konkurentospromozhnosti robochoyi syly na rynku pratsi [Conceptual approaches to determining the labor force competitiveness at the labor market]. Ukrayina: aspekty pratsi - Ukraine: labor aspects, 6, 3-8 [in Ukrainian].

3. Grishnova, O.A. (2001). Formuvannya yakosti robochoyi syly ta konkurentospromozhnosti pratsivnyka v protsesi investuvannya v lyuds'kyy kapital [Formation of the labor force and employee competitiveness in the process of investing in human capital] Konkurentospromozhnist' u sferi pratsi: zb. nauk. prats' - Competitiveness in the labor sphere: collected papers. (pp.117-126). Kyiv: In-t ekonomiky NAN Ukrayiny [in Ukrainian].

4. Kurevina, I.O. (2008). Konkurentospromozhnist' lyuds'koho kapitalu Ukrayiny v umovakh mizhnarodnoyi trudovoyi mihratsiyi [The competitiveness of the human capital of Ukraine in the face of international labor migration]. Extended abstract of candidate's thesis. Kyiv [in Ukrainian].

5. Lisohor, L.S. (2005). Konkurentnist' na rynku pratsi: mekhanizmy realizatsiyi [Competitiveness in the labor market: implementation mechanisms]. Kyiv: In-t demohrafiyi ta sotsial'nykh doslidzhen' NANU [in Ukrainian].

6. Nikolaychuk, M.V. (2011). Konkurentospromozhnist' lyuds'koho kapitalu v systemi suchasnykh chynnykiv rozvytku ekonomiky znan' [The competitiveness of human capital in the system of modern factors of the knowledge economy]. Ekonomichnyy analiz: zb. nauk. prats'-Economical analysis collected papers. Vol.9, (pp. 211-214). Ternopil' [in Ukrainian].

7. Petrova, I.L. (1997). Sehmentatsiya rynku pratsi: teoriya i praktyka rehulyuvannya [Segmentation of the labor market: theory and practice of regulation]. Kyiv: In-t ekonomiky, upravlinnya ta hospodars'koho prava [in Ukrainian].

8. Porter, M. (2001). Mezhdunarodnaya konkurentsyya [International competition]. Moscow: Mezhdunarodnye otnoshenyya [in Russian].

9. Ratnikov, D.H. (2008). Konkurentospromozhnist' trudovoho potentsialu i perspektyvy ekonomichnoho zrostannya [Competitiveness of labor potential and prospects of economic growth]. Rezervy pidvyshchennya efektyvnosti diyal'nosti pidpryyemstv ta orhanizatsiy u XXI stolitti, Tezy dopovidey uchasnykiv Vseukrayins'koyi naukovo-praktychnoyi konferentsiyi molodykh vchenykh, aspirantiv ta studentiv. (pp. 95- 96). Kirovohrad: KNTU [in Ukrainian].

10. Ratnikov, D.H. (2006). Metodyka otsinky rivnya konkurentospromozhnosti robochoyi syly [Methods of the labor force evaluation]. Ukrayina: aspekty pratsi - Ukraine: labor aspects, 1, 8-12 [in Ukrainian].

11. Rehional'nyy lyuds'kyy rozvytok. Statystychnyy byuleten. [The Regional Human Development. Statistical Bulletin]. (2011). Kyiv: Derzhavna sluzhba statystyky [in Ukrainian].

12. Semykina, M. V, Smirnov, O.O. (2008). Konkurentospromozhnist' personalu pidpryyemstva: teoriya i praktyka rehulyuvannya [Personnel competitiveness: Theory and Practice of regulation]. Kirovohrad: KOD [in Ukrainian].

13. Slavhorods'ka, O. Yu., Shcherbak, V.H. Klasyfikatsiya konkurentnykh perevah personalu pidpryyemstva [Classification of personnel competitive advantages], Naukovi pratsi DonNTU: Seriya Ekonomichna, 8, 94-101 [in Ukrainian].

14. Fatkhutdynov, R.A. (2002). Konkurentosposobnost' orhanyzatsyy v uslovyyakh kryzysa: эkonomyka, marketynh, menedzhment [Competitiveness of the organization in times of crisis: economy marketing, management]. Moscow: Marketynh [in Russian].

15. Khafyzova, H. (2012). Razvytye ynnovatsyonnosty y konkurentosposobnosty chelovecheskoho kapytala [The development of the human capital competitiveness]. Kreatyvnaya ekonomyka-Creative economy, 1 (61), 72-82. Retrieved from: http://www.creativeconomy.ru/articles/15311/ [in Russian].

16. Tsvetkova, Y.Y. (2007). Upravlenye konkurentosposobnost'yu personala predpryyatyya [The management of personnel competitiveness]. Symferopol': DOLYa [in Russian].

17. Tsymbal, O.I. (1999). Do vyznachennya katehoriyi konkurentospomozhnist' stosovno robochoyi syly $\mathrm{v}$ umovakh funktsionuvannya ekonomiky perekhidnoho typu [To the definition of competitiveness in relation to the labor force in terms of the transitional economy]. Zaynyatist' ta rynok pratsi - Employment and labor market, 9, 216-227. Kyiv: Rada po vyvchennyu produktyvnykh syl Ukrayiny [in Ukrainian].

Стаття надійшла до редакції журналу 28.07.2014 